\title{
Hyperthermophilic endoglucanase for in planta lignocellulose conversion
}

\author{
Holger Klose ${ }^{1}$, Juliane Röder ${ }^{1}$, Michele Girfoglio ${ }^{1,2}$, Rainer Fischer ${ }^{3,1}$ and Ulrich Commandeur ${ }^{\text {** }}$
}

\begin{abstract}
Background: The enzymatic conversion of lignocellulosic plant biomass into fermentable sugars is a crucial step in the sustainable and environmentally friendly production of biofuels. However, a major drawback of enzymes from mesophilic sources is their suboptimal activity under established pretreatment conditions, e.g. high temperatures, extreme $\mathrm{pH}$ values and high salt concentrations. Enzymes from extremophiles are better adapted to these conditions and could be produced by heterologous expression in microbes, or even directly in the plant biomass.

Results: Here we show that a cellulase gene (sso1354) isolated from the hyperthermophilic archaeon Sulfolobus solfataricus can be expressed in plants, and that the recombinant enzyme is biologically active and exhibits the same properties as the wild type form. Since the enzyme is inactive under normal plant growth conditions, this potentially allows its expression in plants without negative effects on growth and development, and subsequent heat-inducible activation. Furthermore we demonstrate that the recombinant enzyme acts in high concentrations of ionic liquids and can therefore degrade a-cellulose or even complex cell wall preparations under those pretreatment conditions.
\end{abstract}

Conclusion: The hyperthermophilic endoglucanase SSO1354 with its unique features is an excellent tool for advanced biomass conversion. Here we demonstrate its expression in planta and the possibility for post harvest activation. Moreover the enzyme is suitable for combined pretreatment and hydrolysis applications.

Keywords: Sulfolobus solfataricus, Cellulases, Biomass processing, lonic liquids, Plants

\section{Background}

The conversion of lignocellulosic biomass into fuels and commodity chemicals could provide a sustainable alternative to processes based on non-renewable fossil fuel resources. Common strategies to convert lignocellulose into fermentable sugars involve various pretreatment steps followed by enzymatic hydrolysis. Pretreatment methods are usually harsh, involving strong acidic or alkaline solutions, high temperatures and pressures, and the presence of organic solvents [1]. These are features of contemporary chemical processing methods such as diluted acid hydrolysis, ammonia fiber explosion (AFEX) and organosolv, also the use of ionic liquids to dissolve lignocellulose has recently emerged as a promising alternative for biomass pretreatment [2]. Hydrolytic enzymes are commonly produced by microbial fermentation, and

\footnotetext{
* Correspondence: commandeur@molbiotech.rwth-aachen.de 'Institute for Molecular Biotechnology (Biology VII), RWTH Aachen University, Worringerweg 1, 52074, Aachen, Germany

Full list of author information is available at the end of the article
}

despite various improvements in this field the costs are still high [3]. The high energy input required for pretreatment and the expense of enzyme production in microbes means that the conversion of lignocellulosic biomass into fermentable sugars remains economically and environmentally unsustainable $[4,5]$.

Plants can be used as an alternative platform for manufacturing lignocellulolytic enzymes because they can be grown inexpensively on a large scale, which reduces water use and greenhouse gas emissions compared to microbial fermentation [6]. The greatest potential benefit offered by plants is that biomass-degrading enzymes can be produced within the plant biomass itself. Importantly, this approach can only be successful if the enzymatic activity does not inhibit plant growth and development, and biomass pretreatments do not destroy the enzymes [6,7].

Cellulases have been produced in a number of plant species $[8,9]$ and the expressed and isolated recombinant enzymes have been shown to digest cell wall preparations

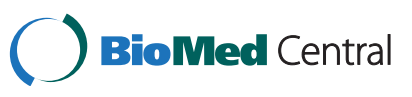

(c) 2012 Klose et al.; licensee BioMed Central Ltd. This is an Open Access article distributed under the terms of the Creative Commons Attribution License (http://creativecommons.org/licenses/by/2.0), which permits unrestricted use, distribution, and reproduction in any medium, provided the original work is properly cited. 
$[10,11]$. However, the constitutive expression of mesophilic cellulases in plants eventually resulted in abnormal phenotypes such as stunting and deformation [12] reflecting changes in the structure and lower recalcitrance of cell walls [13]. To avoid these detrimental effects, cellulases have been targeted to intracellular compartments so that direct contact with cell wall polysaccharides is avoided until after harvesting and pretreatment, which results in cell disruption [14].

The degradation of plant cell walls during normal growth can also be avoided by the expression of thermophilic cellulases because their temperature optima often lie outside the physiological range for mesophilic plant growth $[11,15]$. Thermophilic cellulases should also be more compatible with standard pretreatments. For example, Acidothermus cellulolyticus endoglucanase E1 was expressed in transgenic tobacco plants that were subjected to AFEX pretreatment, and approximately $30 \%$ of the enzyme activity was retained [16]. Several ionic liquids have been evaluated as lignocellulose solvents, and these can be combined with enzymatic hydrolysis although the enzymes must retain their activity in high concentrations of ionic liquids with a water content of only 10-20\% [17].

Extremophilic microorganisms can tolerate high temperatures, extreme $\mathrm{pH}$ values and strong salt solutions, therefore offering an ideal source of enzymes that convert lignocellulose into fermentable sugars $[18,19]$. The genome of the hyperthermophilic archaeon Sulfolobus solfataricus encodes three different endoglucanases (SSO1354, SSO1949 and SSO2534) [20] that have already shown their potential to perform efficiently under harsh physical and chemical conditions [21-24]. Here we achieved the expression of SSO1354 in tobacco (Nicotiana tabacum) and determined its ability to convert plant biomass into fermentable sugars under different pretreatment conditions, offering a promising new approach for the bioconversion of lignocellulose in planta.

\section{Results}

\section{Expression and purification of SSO1354}

The sso1354 gene was amplified from Sulfolobus solfataricus genomic DNA without the coding region of the putative leader peptide [23]. Investigation of putative $\mathrm{N}$-glycosylation sites (matching the consensus Asn-XSer/Thr) using the web tool "NetNGlyc 1.0 Server" (available at http://www.cbs.dtu.dk/services/NetNGlyc) revealed the presence of 10 potential $\mathrm{N}$-glycosylation sites.

The amplified sequences were flanked by either $\mathrm{N}$-terminal or C-terminal $\mathrm{His}_{6}$ tags and an optional C-terminal KDEL sequence for retention in the endoplasmic reticulum (ER) was also included, depending on the primers. These products were transferred to the pTRAkc expression vector. The expression cassette contained the Cauliflower mosaic virus (CaMV) double 35SS promoter, the 5'-UTR translational enhancer from the Petroselinum hortense chalcone synthase gene and a plant codon optimized LPH signal peptide for secretion to the apoplast (Figure 1).

The expression vectors were introduced into $A$. tumefaciens strain GV3101, which was infiltrated into tobacco leaves. The infiltrated leaves were harvested after 4 days, total soluble protein (TSP) were extracted and analyzed by SDS-PAGE, activity staining and Western blot.

Initial transient expression tests showed that enzyme variants with a $\mathrm{C}$-terminal $\mathrm{His}_{6}$ tag could not be detected in the infiltrated plants. However constructs carrying an $\mathrm{N}$-terminal $\mathrm{His}_{6}$ tag either with or without the KDEL sequence were detectable by Western Blot analysis (Figure 2A). The ER-localized variant showed the highest azocarboxymethylcellulase (Azo-CMC) activity per gram leaf material (data not shown) and was selected for expression in transgenic plants and further analysis.

$\mathrm{T}_{0}$ transgenic plants expressing the ER-tagged enzyme were transferred to soil and maintained in the greenhouse. The leaves were screened for enzyme activity using the substrate SDS-PAGE method, and $\mathrm{T}_{1}$ seeds from positive candidates were used to produce the next generation of plants (data not shown). The leaves from the $T_{1}$ plants were tested using the substrate 4-methylumbelliferyl- $\beta$-D-cellobioside (4MUC) to determine the activity of the recombinant SSO1354 protein, which ranged from 92 to $488 \mathrm{nmol} 4 \mathrm{MU} \mathrm{min}{ }^{-1} \mathrm{mg}^{-1}$ in different transgenic lines (Figure 3A). The morphology and growth behavior of the transgenic plants were no different to those of wild-type SR1 plants (Figures 3B and C).

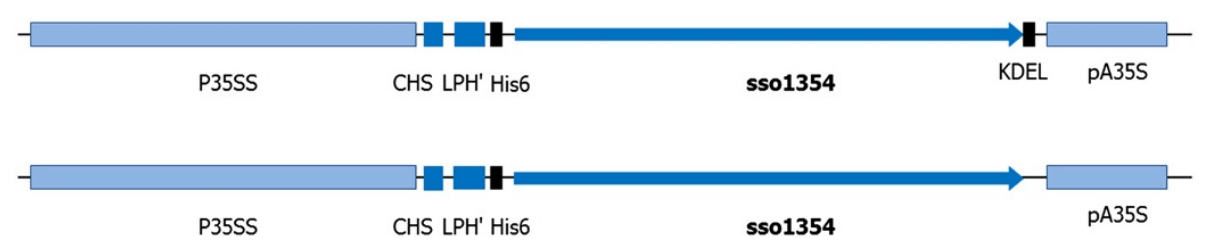

Figure 1 Schematic representation of SSO1354 expression cassettes from the constructs including an N-terminal His ${ }_{6}$ tag. The double CaMV promoter (P35SS) and terminator (pA35S) are shown in light blue and the chalcone synthase 5'-UTR (CHS) and codon-optimized leader from the murine antibody peptide mAb24 (LPH) are shown in dark blue. The His and KDEL coding sequences are indicated in black. 


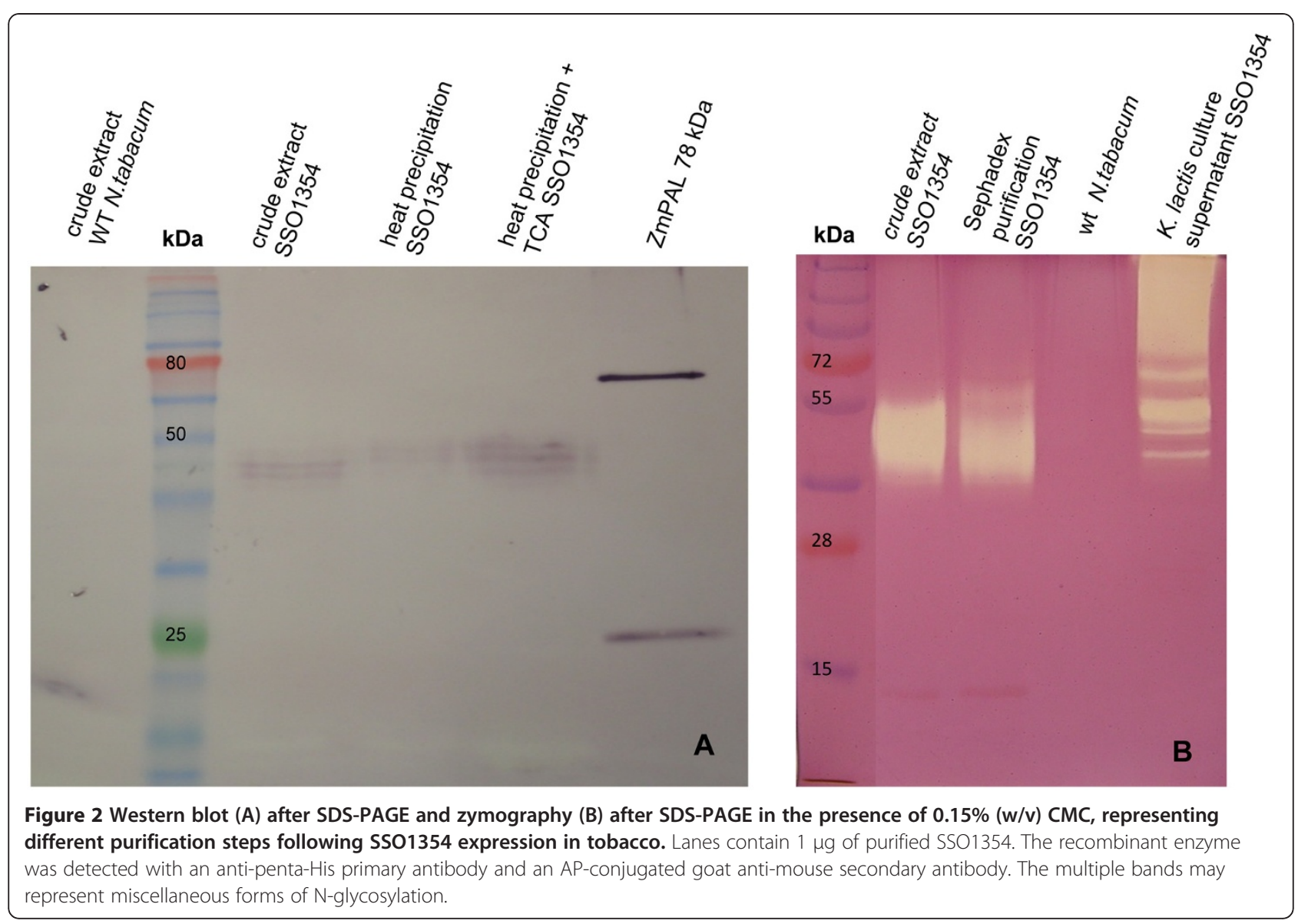

The recombinant SSO1354 was partially purified from crude plant extracts by thermal precipitation. Heating to $85^{\circ} \mathrm{C}$ for 10 min caused $95 \%$ of the host cell proteins to precipitate whereas SSO1354 remained soluble and active. Reducing sugars in the extract, which could potentially interfere with subsequent enzyme activity assays, were removed by passing the remaining extract through a PD10 desalting column (Figure 2B).

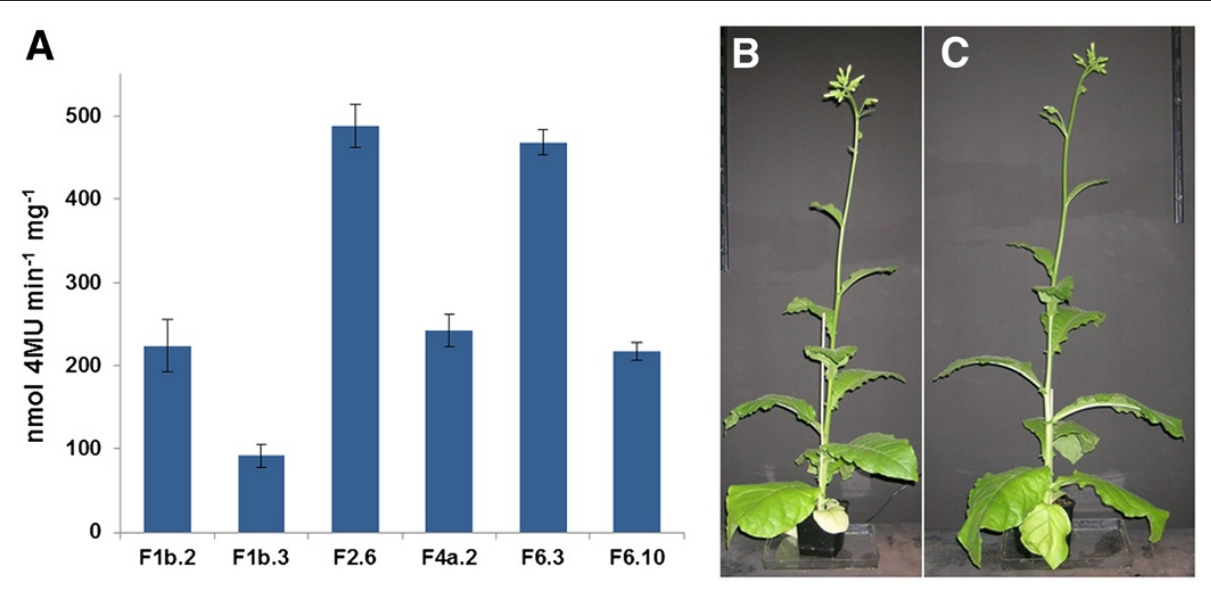

Figure 3 Expression of SSO1354 in transgenic tobacco lines. Quantification of expression by 4MUC conversion (A). Phenotype of a transgenic tobacco plant expressing SSO1354 (B) and wild type SR1 tobacco (C), both grown in soil under greenhouse conditions. 


\section{Biochemical properties and catalytic activity of plant- derived SSO1354}

The substrate profile of SSO1354 was determined by testing against a panel of $\beta$-glucans. A p-hydroxybenzoic acid hydrazide (PAHBAH) assay was used to measure the release of reducing sugars, showing that SSO1354 was active against CMC (arbitrary value set at $100 \%$ activity) and also barley $\beta$-glucan (136\% relative activity) and lichenan (130\% relative activity), but not against PCM3/pachyman. This suggests that SSO1354 has a $\beta-1,4$ hydrolytic mode of action. The enzyme showed no significant activity on Avicel $^{\circledR}$, a microcrystalline cellulose, or on oat xylan.

Further analysis using an Azo-CMC assay showed that SSO1354 has an optimum temperature at $90^{\circ} \mathrm{C}$, although it retained $79 \%$ residual activity at $99^{\circ} \mathrm{C}$. The activity was intensely reduced at lower temperatures, falling to $24 \%$ residual activity at $70^{\circ} \mathrm{C}$. The optimal $\mathrm{pH}$ was 4.5 , although the enzyme retained $58 \%$ residual activity at $\mathrm{pH} 2.7$ and $62 \%$ residual activity at $\mathrm{pH} 6.5$ (Figure 4 ). There was only minimal activity below $\mathrm{pH} 2.2$ and above $\mathrm{pH}$ 7.0. At optimal conditions $\left(90^{\circ} \mathrm{C}, \mathrm{pH} 4.5\right)$ the enzyme retained $50 \%$ of its activity after incubation for $100 \mathrm{~min}$. SSO1354 also tolerated high salt concentrations, with $49.5 \%$ residual activity in the presence of $2.4 \mathrm{M} \mathrm{NaCl}$, and $46.5 \%$ residual activity in the presence of $2.4 \mathrm{M} \mathrm{CaCl}_{2}$ (Figure 5).

SSO1354 activity was inhibited by $15 \%(\mathrm{v} / \mathrm{v})$ solutions of both protic solvents (capable of donating protons) such as methanol and ethanol, and aprotic solvents such as acetone and dimethylsulfoxide (DMSO). The enzyme retained $79 \%$ residual activity in the presence of methanol, $75 \%$ in the presence of DMSO, $51 \%$ in the presence of acetone and $48 \%$ in the presence of ethanol. Increasing the solvent concentration to $30 \%(\mathrm{v} / \mathrm{v})$ exacerbated the effect, with methanol and acetone causing nearcomplete inhibition, DMSO leaving a residual activity of $14 \%$ and ethanol leaving a residual activity of $16 \%$.

\section{SSO1354 activity in ionic liquids}

As discussed above, SSO1354 cannot hydrolyze crystalline cellulose or cell wall polysaccharides efficiently in aqueous solutions, but concentrated solutions $(80-90 \% \mathrm{v} / \mathrm{v})$ of ionic liquids such as 1-ethyl-3-methylimidazolium acetate (EMIM-Ac) and 1,3-dimethylimidazolium dimethylphosphate (MMIM-DMP) are able to dissolve crystalline cellulose like Avicel ${ }^{\circledR}$ and cell wall polysaccharides, making them more accessible to hydrolytic enzymes.

We therefore tested the activity of SSO1354 on Avicel ${ }^{\circledR}$ that had been dissolved in $80 \%$ ( $\mathrm{v} / \mathrm{v}$ ) EMIM-Ac and MMIM-DMP by measuring the release of reducing sugars. Sugars released by spontaneous hydrolysis in the absence of the enzyme were measured in control reactions and subtracted from the test reactions, resulting in corrected release rates of $5.5 \mathrm{mg} \mathrm{l}^{-1} \mathrm{~h}^{-1}$ in EMIM-Ac and $3.5 \mathrm{mg}$ $\mathrm{l}^{-1} \mathrm{~h}^{-1}$ in MMIM-DMP (Figure 6A). We also found that cell wall polysaccharides dissolved in EMIM-Ac and MMIM-DMP were hydrolyzed by SSO1354 with a release rate of $1.8 \mathrm{mg} \mathrm{l}^{-1} \mathrm{~h}^{-1}$ for EMIM-Ac and $1.2 \mathrm{mg} \mathrm{l}^{-1} \mathrm{~h}^{-1}$ for MMIM-DMP (Figure 6B).

\section{Discussion}

The conversion of lignocellulosic biomass into fermentable sugars is an important step in the production of second-generation biofuels. A typical approach involves the enzymatic hydrolysis of cellulose using microbial $\beta$-glucanases, but the efficiency of saccharification is limited by the accessibility of the substrate, which must therefore be pretreated [1]. Common cellulase preparations are derived from mesophilic fungi and have an optimal activity at $50^{\circ} \mathrm{C}$ and $\mathrm{pH} 4-5$ [25]. In contrast, standard biomass pretreatment methods are performed under harsher conditions that would invariably denature these enzymes, which means they can only be added after pretreatment [1]. The production of cellulases
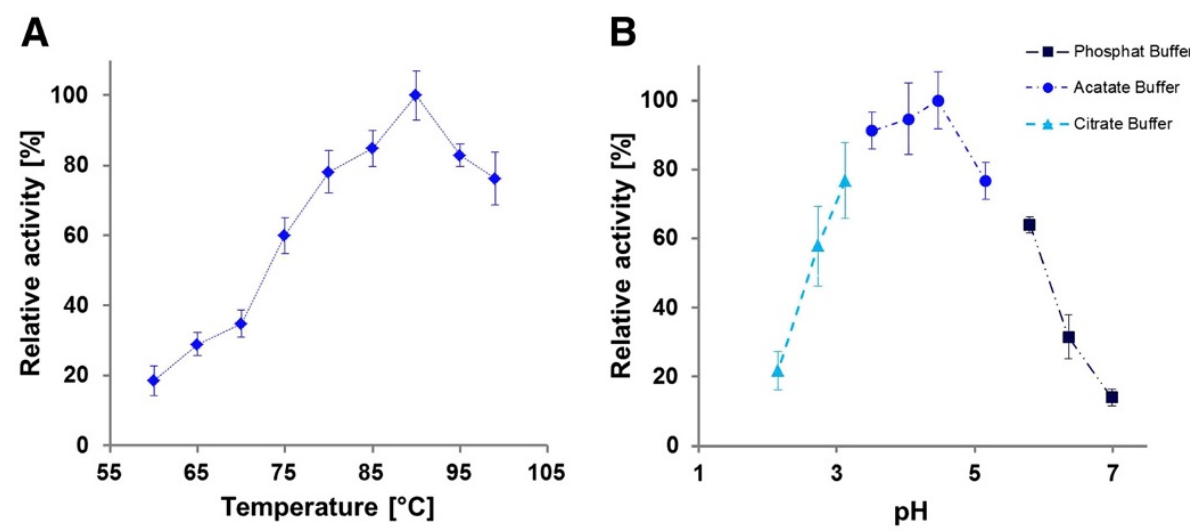

Figure 4 Influence of temperature (A) and pH (B) on SS01354 activity. Conversion of Azo-CMC was measured at $60-99^{\circ} \mathrm{C}$. The maximum activity measured at $90^{\circ} \mathrm{C}$ was set at $100 \%$. Influence of $\mathrm{pH}$ on $\mathrm{SSO} 1354$ activity was measured by Azo-CMC conversion at pH values between 2.0 and 7.0. The maximum activity measured at $\mathrm{pH} 4.5$ was set at $100 \%$. 


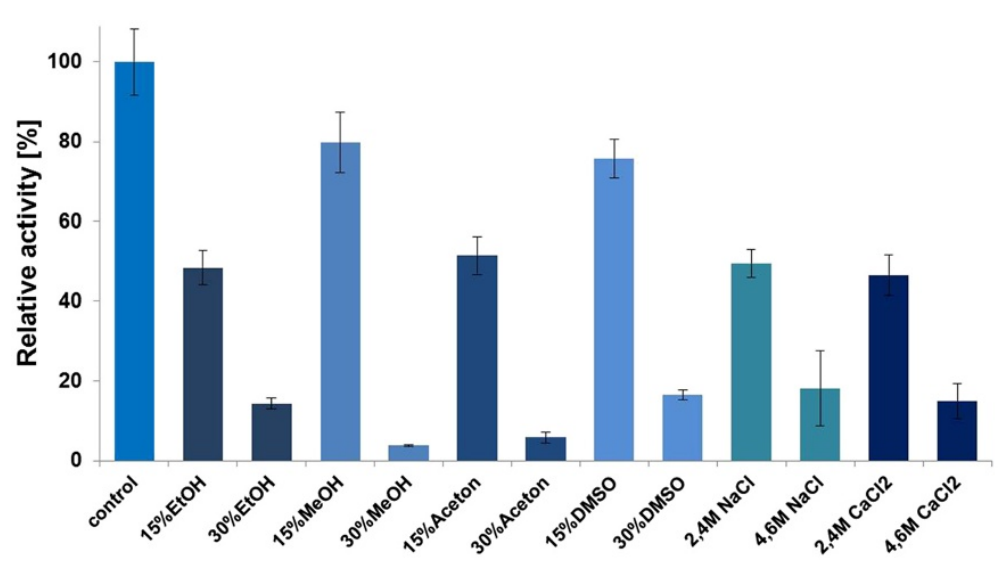

Figure 5 Influence of solvents and different salt concentrations on SSO1354 activity. Activity was measured using the Azo-CMC assay at optimal conditions $\left(90^{\circ} \mathrm{C}, \mathrm{pH} 4.5\right)$ by adding different concentrations of salts and solvents. SSO1354 activity in the absence of salts and solvents was set at $100 \%$.

directly in the biomass targeted for conversion would be more economically and environmentally sustainable than microbial fermentation, but commonly used mesophilic enzymes would be incompatible with current pretreatment regimens $[4,26]$. Constitutively expressed and secreted mesophilic cellulases can also inhibit normal plant growth, by reducing the integrity of the cell wall and therefore leaving the plant vulnerable to environmental stresses [13]. One solution to this problem is the sequestration of recombinant cellulases into subcellular compartments with no direct access to cell wall components, and previous studies have demonstrated the feasibility of this approach $[9,27]$. The expression of cellulases from hyperthermophilic organisms is a promising alternative because the temperature optima of these enzymes would ensure normal plant growth and development at physiological temperatures and enzyme survival and activity under conventional pretreatment conditions.

The sso1354 gene from S. solfataricus encodes an endo- $\beta$-glucanase from GH family 12 [20] and does not contain a cellulose binding module (CBM). This enzyme is active at high temperatures and at low $\mathrm{pH}$ conditions, and it is one of the first enzymes known to retain their activity in high concentrations of ionic liquids [23]. These features make SSO1354 an ideal candidate for enzymatic biomass conversion directly in plants.

We demonstrated that SSO1354 can be functionally expressed in tobacco plants by targeting the protein either for secretion into the apoplast or for retention in the ER. The addition of a $\mathrm{His}_{6}$ tag to the $\mathrm{N}$-terminus and an optional C-terminal KDEL sequence had no adverse effects on enzyme activity. The inclusion of the KDEL sequence resulted in different detectable forms of the protein, with molecular weights between 40 and $50 \mathrm{kDa}$. The predicted molecular weight of the protein was $38 \mathrm{kDa}$, and the discrepancy may reflect the presence of glycan residues on one or more of the 10 putative $\mathrm{N}$-glycan acceptor sites.

Analysis of the phenotype revealed no significant difference between wild-type tobacco and transgenic lines
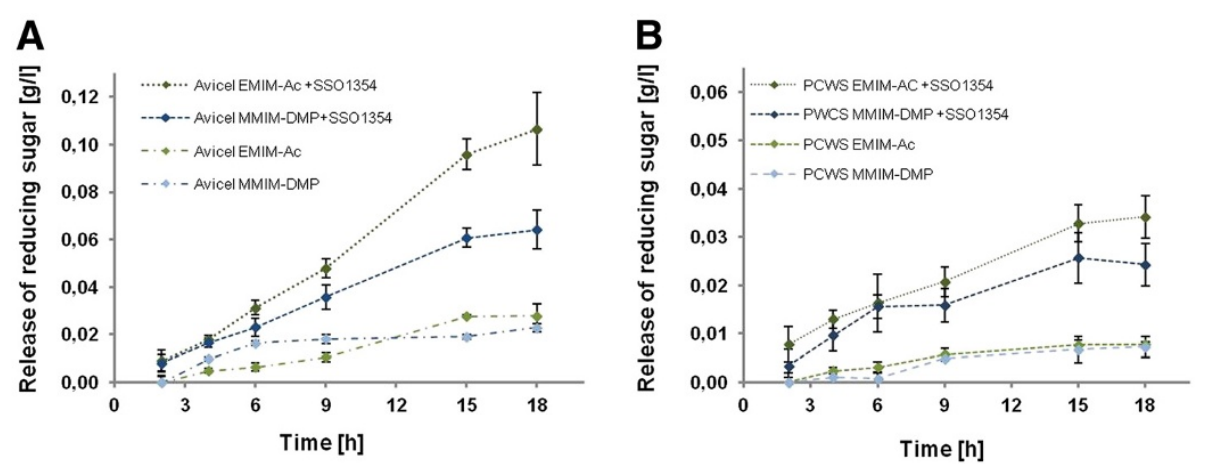

Figure 6 Activity of SSO1354 on (A) $0.5 \%(\mathrm{w} / \mathrm{v})$ Avicel $^{\circledR}$ and (B) tobacco-derived cell wall polysaccharides (PCWS) dissolved in $80 \%$ (v/v) EMIM-Ac or MMIM-DMP. Assays were carried out at $90^{\circ} \mathrm{C}$. The amount of reducing sugar was measured using the PAHBAH assay. 
producing SSO1354 underlining that the enzyme stays inactive at plant growth conditions. The activity of plant-derived SSO1354 reached a maximum of $0.5 \mu \mathrm{mol}$ 4MU min ${ }^{-1} \mathrm{mg}^{-1}$, which represents a yield of $1.1 \% \mathrm{TSP}$. This yield is lower than has been reported for other cellulolytic enzymes in plant expression systems $[9,28]$. However, it may be possible to improve the yields by various means e.g. codon optimization.

We confirmed the known features of SSO1354 [23,24] but we also discovered some novel characteristics, such as the efficient hydrolysis of substrates with $\beta$-1,4-linked glucose units. There was no hydrolysis of crystalline cellulose or substrates lacking $\beta-1,4$ linkages, nor did we observe the hydrolysis of substrates like oat xylan, which comprises $\beta$-1,4-linked xylose, even though such activity has been reported previously [24]. This confirms that the enzyme is a strict endo- $\beta-1,4$-glucanase. The enzyme has a temperature optimum of $90^{\circ} \mathrm{C}$, which is the highest reported temperature for any cellulase expressed in plants and one of the highest in any heterologous expression system $[22,29,30]$. The activity of the enzyme drops sharply as the temperature declines, displaying only $25 \%$ activity at $70^{\circ} \mathrm{C}$ and virtually no activity at temperatures below $30^{\circ} \mathrm{C}$ (data not shown), suggesting there would be no hydrolysis of plant cellulose under normal plant growth conditions. This is supported by the normal morphological phenotype of the transgenic plants (Figures 3B and C) and suggests that post-harvest cellulose hydrolysis could be induced by a temperature shift.

SSO1354 is also advantageous because it tolerates a relatively broad $\mathrm{pH}$ range $(2.7-6.5$, retaining at least $60 \%$ residual activity) whereas SSO1949 from the same species has a sharp optimum at $\mathrm{pH} 1.8$ [22]. Under the optimal conditions ( $\mathrm{pH} 4.5$ and $90^{\circ} \mathrm{C}$ ), SSO1354 retains $85 \%$ activity after $1 \mathrm{~h}$ of incubation. In addition to its remarkable thermostability and $\mathrm{pH}$ tolerance, SSO1354 also tolerates moderate levels of organic solvents and high levels of salt.

Ionic liquids are very efficient in dissolving crystalline cellulose, however they are still expensive [17,31]. Promising results of their recycling have been published recently [31]. A unique feature of SSO1354 is its activity in ionic liquids such as EMIM-Ac and MMIM-DMP. SSO1354 was able to produce $5.5 \mathrm{mg} \mathrm{l}^{-1} \mathrm{~h}^{-1}$ of reducing sugars from Avicel ${ }^{\circledR}$ dissolved in EMIM-Ac, which is low compared to other soluble substrates but still highly promising for future optimization. The hydrolysis rate was $3.5 \mathrm{mg} \mathrm{l}^{-1} \mathrm{~h}^{-1}$ in MMIM-DMP, showing this is a less suitable ionic liquid for SSO1354-catalyzed biomass hydrolysis.

Although testing SSO1354 on artificial substrates confirmed its activity under a range of conditions, plant biomass is a complex substrate with different components such as cellulose, hemicelluloses and lignin, the latter acting as a significant inhibitor of cellulases (hence the need for pretreatment) [32]. To investigate the activity of SSO1354 against such complex substrates, we exposed the enzyme to cell wall polysaccharides from tobacco leaves. This substrate is more heterogeneous than crystalline cellulose but it has a $\sim 0.8 \%$ (dry weight) lignin content and is therefore less complex than material derived from tobacco roots or stems [33]. SSO1354 showed no significant activity against cell wall polysaccharides in aqueous suspension, as determined by the release of reducing sugars, but when the substrate was dissolved in ionic liquids the results were more impressive. The enzyme released $1.8 \mathrm{mg} \mathrm{l}^{-1} \mathrm{~h}^{-1}$ of reducing sugars in EMIM-Ac and $1.2 \mathrm{mg}^{-1} \mathrm{~h}^{-1}$ in MMIM-DMP. These data indicate the possibility of combined pretreatment and enzymatic hydrolysis.

\section{Conclusion}

The use of plants as an enzyme production system and subsequent utilization requires two important criteria to be satisfied. The enzyme must not interfere with cell wall synthesis or integrity and it must tolerate the extreme conditions found in standard pretreatment processes. Hyperthermophilic cellulases like the endoglucanase SSO1354 from S. solfataricus combine both features. This study demonstrates the successful production of inactive SSO1354 at normal growth conditions followed by the induction of enzyme activity at higher temperatures. To our knowledge, SSO1354 is the first enzyme expressed in planta that remains active in ionic liquids such as EMIM-Ac and MMIM-DMP, which are used for biomass pretreatment. Plants have already been developed as a powerful platform for the expression of biomassprocessing enzymes, but the use of enzymes that function optimally under harsh pretreatment conditions opens the way to develop combined pretreatment and enzymatic hydrolysis strategies for the efficient conversion of lignocellulosic plant biomass into fermentable sugars.

\section{Methods}

\section{Plant material and bacterial strains}

Tobacco plants (Nicotiana tabacum L. cv. Petit Havana SR1) were cultivated in the greenhouse with a 16-h photoperiod (5000-10,000 Lux), 70\% relative humidity and $25 / 22^{\circ} \mathrm{C}$ day/night temperature. For transient expression and plant transformation Agrobacterium tumefaciens strain GV3101::pMP90RK $\left(\mathrm{Gm}^{\mathrm{R}} \mathrm{Km}^{\mathrm{R}} \mathrm{Rif}^{\mathrm{R}}\right)$ was used [34].

\section{Cloning}

We used binary vectors pTRAkc-AH and pTRAkc-ERH, both of which carry the CaMV 35SS double promoter for constitutive transgene expression [35]. The coding sequence of the SSO1354 catalytic domain (AAK41590.1, EMBL-CDS) was amplified by PCR from $S$. solfataricus P2 genomic DNA (kindly provided by Raffaele Cannio, 
Institute for Microelectronics and Microsystems, Naples, Italy) using the primers sso1354-fw-BspHI (5'-AAT CAT GAA GCA GTC TCT CAG CGT TAA ACC CG-3') and sso1354-rv-NotI (5'-AAG CGG CCG CGA GGA GAG TTT CAG AAA AG-3') to generate the product sso1354$\mathrm{His}_{6}$ with a C-terminal $\mathrm{His}_{6}$ tag. The purified fragment was transferred to the pCR2.1 vector (Invitrogen) by TAcloning to generate construct pCR2.1-SSO1354. This was digested with BspHI and NotI and the released cassette was inserted into the pTRAkc-AH and pTRAkc-ERH vectors (previously digested with NcoI and NotI). An analogous process, substituting primers sso1354-fw-BspHI-His6 (5'-TCA TGA AAC ATC ACC ATC ACC ATC ACG CGG CCG CTC AGT CTC TCA GCG TTA AAC CCG T-3') and sso1354-rv-XhoI (5'-AAC TCG AGT TAG AGG AGA GTT TCA GAA AAG-3') or sso1354-rv-KDEL-XhoI (5'-AAC TCG AGC TAG AGC TCA TCT TTG AGG AGA GTT TCA GAA AAG-3'), was used to generate constructs with an $\mathrm{N}$-terminal $\mathrm{His}_{6}$ tag, with or without a C-terminal KDEL signal.

\section{Agroinfiltration and generation of transgenic plants} Electrocompetent Agrobacterium tumefaciens cells [36] were transformed with either pTRAkc-AH or pTRAkcERH and were selected on YEP medium plates $\left(10 \mathrm{~g} \mathrm{l}^{-1}\right.$ Bacto Tryptone, $10 \mathrm{~g} \mathrm{l}^{-1}$ yeast extract, $5 \mathrm{~g} \mathrm{l}^{-1} \mathrm{NaCl}, 15 \mathrm{~g} \mathrm{l}^{-1}$ agar, pH 7.0) supplemented with kanamycin (50 $\mathrm{mg} \mathrm{ml}^{-1}$ ), rifampicin (50 mg ml${ }^{-1}$ ) and carbenicillin $\left(100 \mathrm{mg} \mathrm{ml}^{-1}\right)$.

Colonies were transferred to liquid YEP medium containing kanamycin $\left(50 \mathrm{mg} \mathrm{ml}^{-1}\right)$, rifampicin $\left(50 \mathrm{mg} \mathrm{ml}^{-1}\right)$ and carbenicillin $\left(100 \mathrm{mg} \mathrm{ml}^{-1}\right)$ for $36-40 \mathrm{~h}\left(26^{\circ} \mathrm{C}\right.$, $180 \mathrm{rpm}$ ) for selection. The suspensions were supplemented with $10 \mu \mathrm{M}$ acetosyringone, $10 \mathrm{mM}$ MES (pH 5.6) and $10 \mathrm{mM}$ glucose, and the bacteria were incubated for another $20 \mathrm{~h}$. The $\mathrm{OD}_{600}$ of the culture was adjusted to 1.0 with $2 x$ infiltration medium $(0.86 \%$ MS salts, $10 \%$ sucrose, $0.36 \%$ glucose, $\mathrm{pH} 5.6$ ) and the adjusted suspension was supplemented with $200 \mu \mathrm{M}$ acetosyringone prior to incubation for $45 \mathrm{~min}$ at room temperature.

Transgenic tobacco lines were generated using the leaf disc transformation method [37]. $\mathrm{T}_{0}$ plants were grown on MS medium containing $100 \mathrm{mg} \mathrm{l}^{-1}$ kanamycin and $200 \mathrm{mg} \mathrm{l}^{-1}$ Claforan $^{\circledR}$ (cefotaxime) before transfer to soil in the greenhouse. The $\mathrm{T}_{0}$ plants were self-pollinated to generate $\mathrm{T} 1$ seeds.

\section{Protein extraction and purification}

Infiltrated leaves were ground in liquid nitrogen and homogenized in phosphate buffered saline (PBS; pH 7.0) supplemented with $1 \mathrm{mM}$ phenylmethylsulfonylfluoride (PMSF). The extract was centrifuged at $15,000 \times g$ for $20 \mathrm{~min}$ at $4^{\circ} \mathrm{C}$ followed by filtration to remove suspended particles from the extract. Bulk proteins were removed by heat precipitation at $85^{\circ} \mathrm{C}$ for $10 \mathrm{~min}$ and the recombinant enzyme was separated from small molecules such as sugars by gel filtration (PD-10 Columns, GE Healthcare). Total protein levels were determined using the Bradford method [38] with bovine serum albumin (Roth) as the standard.

\section{Substrate SDS-PAGE and Western blot}

Protein samples were separated by SDS-PAGE in a $12 \%$ polyacrylamide gel containing $0.15 \%(\mathrm{w} / \mathrm{v})$ carboxymethylcellulose $(\mathrm{CMC})$. The proteins were then renatured by washing the gels twice at room temperature for $15 \mathrm{~min}$ with $50 \mathrm{mM}$ sodium acetate buffer $(\mathrm{pH} 4.8)$ containing $20 \%(\mathrm{v} / \mathrm{v})$ propan-2-ol followed by washing twice for 30 min with the same buffer containing no propan-2-ol.

The samples were incubated in sodium acetate buffer at $85^{\circ} \mathrm{C}$ for $20 \mathrm{~min}$ and then in $50 \mathrm{mM}$ Tris $-\mathrm{HCl}$ $(\mathrm{pH} 7.5)$ for $30 \mathrm{~min}$ at room temperature to stop the reaction. The gels were stained for $30 \mathrm{~min}$ in $0.1 \%(\mathrm{w} / \mathrm{v})$ Congo Red (Sigma) and destained in $1 \mathrm{M} \mathrm{NaCl}$. To achieve a higher contrast between degradation and nondegradation areas, the gel was incubated after destaining with $0.5 \%(\mathrm{v} / \mathrm{v})$ acetic acid.

For Western blot analysis, proteins separated by SDSPAGE were electro-transferred (60 $\mathrm{min}, 250 \mathrm{~mA}$ ) to nitrocellulose membranes, blocked for $1 \mathrm{~h}$ at room temperature with $5 \%(\mathrm{w} / \mathrm{v})$ skimmed milk dissolved in PBS, and probed with a monoclonal antibody against penta-His (Qiagen). After washing, the signal was detected with a secondary monoclonal alkaline phosphataseconjugated goat anti-mouse antibody (Dianova) and visualized with nitroblue tetrazolium and 5-bromo-4-chloro-3indolyphosphate (NBT/BCIP; Roth).

\section{Enzymatic assays}

Endoglucanase assays using the substrate 4MUC (Sigma Aldrich) were carried out as described in $50 \mathrm{mM}$ sodium acetate buffer ( $\mathrm{pH} 4.5$ ) containing $0.5 \mathrm{mM}$ 4MUC [39] The conversion rate was calculated against $4 \mathrm{MU}$ standards ranging from 0.05 to $2 \mathrm{nmol}$. For the calculation of the expression rate in \% of TSP, measured activity values were compared to a purified recombinant SSO1354 preparation.

The soluble chromogenic substrate AZO-CM-Cellulose (Megazyme) was used to determine the temperature, $\mathrm{pH}$ and salt tolerance of the recombinant enzyme in aqueous solutions as previously described [40]. Thermotolerance $\left(70-100^{\circ} \mathrm{C}\right)$ was determined using $50 \mathrm{mM}$ acetate buffer $(\mathrm{pH} 4.5), \mathrm{pH}$ tolerance was determined at $90^{\circ} \mathrm{C}$ using $50 \mathrm{mM}$ citrate buffer ( $\mathrm{pH}$ 2.0-3.5), $50 \mathrm{mM}$ acetate buffer (pH 3.5-5.5) and $50 \mathrm{mM}$ phosphate buffer ( $\mathrm{pH} 5.5-7.0)$. Salt tolerance was determined using $50 \mathrm{mM}$ acetate buffer $(\mathrm{pH} 4.5)$ at $90^{\circ} \mathrm{C}$ supplemented with up to $4.6 \mathrm{M} \mathrm{NaCl}$. We took five replicates at each measurement point. 


\section{Determination of activity in ionic liquids}

We tested enzyme activity in 1-ethyl-3-methylimidazolium acetate (EMIM-Ac) and 1,3-dimethylimidazolium dimethylphosphate (MMIM-DMP), both diluted to $80 \%$ $(\mathrm{v} / \mathrm{v})$ in water, using either Avicel ${ }^{\circledR}$ or tobacco-derived cell wall polysaccharides as the substrate $(0.5 \% \mathrm{w} / \mathrm{v})$. The aqueous-buffered enzyme was added to a final concentration of $0.2 \mathrm{~g} \mathrm{l}^{-1}$ and $20 \%(\mathrm{v} / \mathrm{v})$ buffer in the reaction mixture. The reaction mixture was incubated in an Eppendorf Thermomixer at $1000 \mathrm{rpm}$ and $90^{\circ} \mathrm{C}$ and samples were taken at intervals to determine reducing sugar levels.

The reaction was stopped by cooling each sample and the cellulose was precipitated by adding one volume of water followed by centrifugation $(15,000 \times g$ for $2 \mathrm{~min})$. Three phenol-chloroform (1:1) extractions steps and one chloroform extraction were carried out to separate the hydrolysis products and proteins from the ionic liquid. The reducing sugar content was measured using the p-hydroxybenzoic acid hydrazide (PAHBAH) assay by mixing one volume of sample with two volumes of PAHBAH reagent [41]. The solution was incubated at $100^{\circ} \mathrm{C}$ for $10 \mathrm{~min}$ and absorbance was measured at $410 \mathrm{~nm}$. Defined concentrations of glucose were used for calibration. Five replicates were measured at each time point.

\section{Preparation of tobacco cell wall polysaccharides}

Tobacco cell wall polysaccharides were prepared as previously described [10]. Briefly, tobacco leaves were harvested and ground to powder under liquid nitrogen followed by two washes with $25 \mathrm{ml}$ distilled water and centrifugation at $20,000 \times \mathrm{g}, 4^{\circ} \mathrm{C}$. The insoluble cell wall material was washed several times with methanolchloroform (1:1) until the green color disappeared completely. The organic solvent was then removed by evaporation and the dried powder was used for enzymatic assays in ionic liquids.

\section{Abbreviations

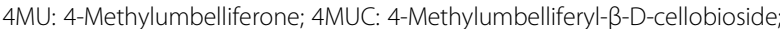 AFEX: Ammonia fiber explosion; BCIP: 5-Bromo-4-chloro-3'-indolyl phosphate p-toluidine; CBM: Cellulose binding module; CMC: Carboxymethylcellulose; DMSO: Dimethylsulfoxide; EMIM-Ac: 1-Ethyl-3-methylimidazolium acetate; ER: Endoplasmic reticulum; GH: Glycoside hydrolase; MES: 2-(N-morpholino) ethanesulfonic acid; MMIM-DMP: 1,3-Dimethylimidazolium dimethylphosphate; NBT: Nitroblue tetrazolium chloride; PAHBAH: p- Hydroxybenzoic acid hydrazide; PBS: Phosphate buffered saline; PMSF: Phenylmethylsulfonylfluoride; SDS: Sodium dodecylsulfate; TSP: Total soluble protein; Tris: Tris(hydroxymethyl)aminomethane; UTR: Untranslated region; YEP: Medium containing Yeast extract and peptone.}

\section{Competing interests}

The authors declare that they have no competing interests.

\section{Authors' contributions}

HK designed and carried out the experiments, analyzed results and wrote the manuscript. JR cloned the SSO1354 gene. MG assisted in the experimental design and reviewed the manuscript. RF and UC coordinated the study and reviewed the manuscript. All authors read and approved the final manuscript.

\section{Acknowledgements}

This work was supported by the BMBF Forschungsinitiative "BioEnergie 2021 - Forschung für die Nutzung von Biomasse" and the Cluster of Excellence "Tailor-made Fuels from Biomass", which is funded through the Excellence Initiative by the German federal and state governments to promote science and research at German universities. The authors gratefully acknowledge Dr. Flora Schuster for generating the transgenic plants.

\section{Author details}

${ }^{1}$ Institute for Molecular Biotechnology (Biology VII), RWTH Aachen University, Worringerweg 1, 52074, Aachen, Germany. ${ }^{2}$ Institute of Protein Biochemistry, CNR, Via P. Castellino 111, 80131, Naples, Italy. ${ }^{3}$ Fraunhofer Institute for Molecular Biology and Applied Ecology (IME), Forckenbeckstrasse 6, 52074, Aachen, Germany.

Received: 25 June 2012 Accepted: 6 August 2012

Published: 28 August 2012

\section{References}

1. Galbe M, Zacchi G: Pretreatment of lignocellulosic materials for efficient bioethanol production. Adv Biochem Eng Biotechnol 2007, 108:41-65.

2. Fu D, Mazza G, Tamaki Y: Lignin extraction from straw by ionic liquids and enzymatic hydrolysis of the cellulosic residues. J Agric Food Chem 2010, 58:2915-2922.

3. Lynd LR, Laser MS, Bransby D, Dale B, Davison B, Hamilton R, Himmel M, Keller M, McMillan JD, Sheehan J, Wyman CE: How biotech can transform biofuels. Nat Biotechnol 2008, 26:169-172.

4. Ragauskas AJ, Williams CK, Davison BH, Britovsek G, Cairney J, Eckert CA Frederick WJ, Hallett JP, Leak DJ, Liotta CL, et al: The Path Forward for Biofuels and Biomaterials. Science 2006, 311:484-489.

5. Aden A, Ruth M, Ibsen K, Jechura J, Neeves K, Sheehan J, Wallace B: Lignocellulosic Biomass to Ethanol Process Design and Economics Utilizing Co-Current Dilute Acid Prehydrolysis and Enzymatic Hydrolysis for Corn Stover. NREL/TP-510-32438 National Renewable Energy Laboratory 2002.

6. Sainz M: Commercial cellulosic ethanol: The role of plant-expressed enzymes. In Vitro Cellular \& Developmental Biology - Plant 2009, 45:314-329.

7. Sticklen M: Plant genetic engineering to improve biomass characteristics for biofuels. Curr Opin Biotechnol 2006, 17:315-319.

8. Ziegelhoffer T, Will J, Austin-Phillips S: Expression of bacterial cellulase genes in transgenic alfalfa (Medicago sativa L.), potato (Solanum tuberosum L.) and tobacco (Nicotiana tabacum L.). Mol Breed 1999, 5:309-318.

9. Dai Z, Hooker BS, Quesenberry RD, Thomas SR: Optimization of Acidothermus cellulolyticus endoglucanase (E1) production in transgenic tobacco plants by transcriptional, post-transcription and posttranslational modification. Transgenic Res 2005, 14:627-643.

10. Kawazu T, Sun JL, Shibata M, Kimura T, Sakka K, Ohmiya K: Expression of a bacterial endoglucanase gene in tobacco increases digestibility of its cell wall fibers. J Biosci Bioeng 1999, 88:421-425.

11. Montalvo-Rodriguez R, Haseltine C, Huess-LaRossa K, Clemente T, Soto J, Staswick P, Blum P: Autohydrolysis of plant polysaccharides using transgenic hyperthermophilic enzymes. Biotechnol Bioeng 2000, 70:151-159.

12. Taylor LE 2nd, Dai Z, Decker SR, Brunecky R, Adney WS, Ding SY, Himmel ME: Heterologous expression of glycosyl hydrolases in planta: a new departure for biofuels. Trends Biotechnol 2008, 26:413-424.

13. Brunecky R, Selig M, Vinzant T, Himmel M, Lee D, Blaylock M, Decker S: In planta expression of $A$. cellulolyticus Cel5A endocellulase reduces cell wall recalcitrance in tobacco and maize. Biotechnology for Biofuels 2011, $4: 1$

14. Hood EE, Love R, Lane J, Bray J, Clough R, Pappu K, Drees C, Hood KR, Yoon S, Ahmad A, Howard JA: Subcellular targeting is a key condition for highlevel accumulation of cellulase protein in transgenic maize seed. Plant Biotechnol J 2007, 5:709-719.

15. Xue GP, Patel M, Johnson JS, Smyth DJ, Vickers CE: Selectable marker-free transgenic barley producing a high level of cellulase (1,4-betaglucanase) in developing grains. Plant Cell Rep 2003, 21:1088-1094. 
16. Teymouri F, Alizadeh H, Laureano-Pérez L, Dale B, Sticklen M: Effects of ammonia fiber explosion treatment on activity of endoglucanase from Acidothermus cellulolyticus.Transgenic Plant 2004, 116.

17. Zavrel M, Bross D, Funke M, Büchs J, Spiess AC: High-throughput screening for ionic liquids dissolving (ligno-)cellulose. Bioresour Technol 2009, 100:2580-2587.

18. Unsworth LD, Van Der Oost J, Koutsopoulos S: Hyperthermophilic enzymes - stability, activity and implementation strategies for high temperature applications. FEBS J 2007, 274:4044-4056.

19. Turner P, Mamo G, Karlsson E: Potential and utilization of thermophiles and thermostable enzymes in biorefining. Microb Cell Fact 2007, 6:9.

20. She Q, Singh RK, Confalonieri F, Zivanovic Y, Allard G, Awayez MJ, ChanWeiher CC-Y, Clausen IG, Curtis BA, De Moors A, et al: The complete genome of the crenarchaeon Sulfolobus solfataricus P2. Proc Natl Acad Sci 2001, 98:7835-7840.

21. Limauro D, Cannio R, Fiorentino G, Rossi M, Bartolucci S: Identification and molecular characterization of an endoglucanase gene celS from the extremely thermophilic archaeon Sulfolobus solfataricus. Extremophiles 2001, 5:213-219.

22. Huang Y, Krauss G, Cottaz S, Driguez H, Lipps G: A highly acid-stable and thermostable endo-beta-glucanase from the thermoacidophilic archaeon Sulfolobus solfataricus. Biochem J 2005, 385:581-588.

23. Girfoglio M, Rossi M, Cannio R: Cellulose degradation by Sulfolobus solfataricus requires a cell anchored endo- $\beta$-1-4-glucanase. J Bacteriol Sep; 2012, 194(18):5091-5100.

24. Maurelli L, Giovane A, Esposito A, Moracci M, Fiume I, Rossi M, Morana A: Evidence that the xylanase activity from Sulfolobus solfataricus $\mathrm{Oa}$ is encoded by the endoglucanase precursor gene (sso1354) and characterization of the associated cellulase activity. Extremophiles 2008 , 12:689-700.

25. Saddler JN, Gregg DJ: Ethanol production from forest product wastes. In Forest Products Biotechnology. Edited by Bruce A, Palfreyman JW. London: Taylor \& Francis Ltd; 1998:183-207.

26. Vogel KP, Jung H-JG: Genetic Modification of Herbaceous Plants for Feed and Fuel. Crit Rev Plant Sci 2001, 20:15-49.

27. Ziegler MT, Thomas SR, Danna KJ: Accumulation of a thermostable endo1,4-D-glucanase in the apoplast of Arabidopsis thaliana leaves. Mol Breed 2000, 6:37-46.

28. Ziegelhoffer T, Raasch JA, Austin-Phillips S: Expression of Acidothermus cellulolyticus E1 endo-beta-1,4-glucanase catalytic domain in transplastomic tobacco. Plant Biotechnol J 2009, 7:527-536.

29. Bauer MW, Driskill LE, Callen W, Snead MA, Mathur EJ, Kelly RM: An Endoglucanase, EglA, from the Hyperthermophilic Archaeon Pyrococcus furiosus Hydrolyzes beta -1,4 Bonds in Mixed-Linkage (1-3), (1-4)-beta -D-Glucans and Cellulose. J Bacteriol 1999, 181:284-290.

30. Bronnenmeier K, Kern A, Liebl W, Staudenbauer W: Purification of Thermotoga maritima enzymes for the degradation of cellulosic materials. Appl Environ Microbiol 1995, 61:1399-1407

31. Abels C, Redepenning C, Moll A, Melin T, Wessling M: Simple purification of ionic liquid solvents by nanofiltration in biorefining of lignocellulosic substrates. J Membr Sci 2012, 405-406:1-10.

32. Rahikainen J, Mikander S, Marjamaa K, Tamminen T, Lappas A, Viikari L, Kruus $\mathrm{K}$ : Inhibition of enzymatic hydrolysis by residual lignins from softwood-study of enzyme binding and inactivation on lignin-rich surface. Biotechnol Bioeng 2011, 108:2823-2834.

33. Lagrimini LM, Gingas V, Finger F, Rothstein S, Liu T: Characterization of Antisense Transformed Plants Deficient in the Tobacco Anionic Peroxidase. Plant Physiol 1997, 114:1187-1196.

34. Koncz C, Schell J: The promoter of T-DNA gene Scontrols the tissuespecific expression of chimaeric genes carried by a novel type of Agrobacterium binary vector. Mol Gen Genet MGG 1986, 204:383-396.

35. Maclean J, Koekemoer M, Olivier AJ, Stewart D, Hitzeroth II, Rademacher T, Fischer R, Williamson A-L, Rybicki EP: Optimization of human papillomavirus type 16 (HPV-16) L1 expression in plants: comparison of the suitability of different HPV-16 L1 gene variants and different cellcompartment localization. J Gen Virol 2007, 88:1460-1469.

36. Shen W-j, Forde BG: Efficient transformation of Agrobacterium spp. by high voltage electroporation. Nucleic Acids Res 1989, 17:8385.

37. Horsch RB, Fry JE, Hoffman NL, Rogers SG, Fraley RT: A Simple and General Method for Transferring Genes into Plants. Science 1985, 227:1229-1231.
38. Bradford $M$ : A rapid and sensitive method for the quantitation of microgram quantities of protein utilizing the principle of protein-dye binding. Anal Biochem 1976, 72:248-254.

39. Ziegelhoffer T, Raasch JA, Austin-Phillips S: Dramatic effects of truncation and sub-cellular targeting on the accumulation of recombinant microbial cellulase in tobacco. Mol Breed 2001, 8:147-158.

40. Jørgensen $\mathrm{H}$, Olsson L: Production of cellulases by Penicillium brasilianum IBT 20888-Effect of substrate on hydrolytic performance. Enzyme Microb Technol 2004, 38:381-390.

41. Lever M: A new reaction for colorimetric determination of carbohydrates. Anal Biochem 1972, 47:273-279.

doi:10.1186/1754-6834-5-63

Cite this article as: Klose et al:: Hyperthermophilic endoglucanase for in planta lignocellulose conversion. Biotechnology for Biofuels 2012 5:63.

\section{Submit your next manuscript to BioMed Central and take full advantage of:}

- Convenient online submission

- Thorough peer review

- No space constraints or color figure charges

- Immediate publication on acceptance

- Inclusion in PubMed, CAS, Scopus and Google Scholar

- Research which is freely available for redistribution 